\title{
Emlékezés Pálinkó István professzorra (1959-2021)
}

\author{
SIPOS Pál ${ }^{*}$ \\ Szegedi Tudományegyetem, TTIK, Szervetlen és Analitikai Kémia Tanszék, Dóm tér 7, H-6721 Szeged
}

Pálinkó István, Stike rövid és súlyos betegség után 62 éves korában ez év március 26-án elhunyt. Nem tudtam tőle személyesen elköszönni, utolsó rövid telefonbeszélgetésünkkor annyit sikerült megtudnom, hogy küzd ugyan, de érezhetően fogytán az ereje. Stikének közismerten a küzdeni tudás volt az egyik védjegye, így akkor még eszembe (eszünkbe) se jutott, hogy alulmaradhat. De ahogy egymás után érkeztek az aggasztó hírek, egyre többször kellett arra gondolnom, ami végül is bekövetkezett, hogy elveszíthetem az egyik legjobb barátomat.

Stike egy évvel előttem járt az egyetemen, az 1978-ban indult vegyész évfolyam egyik legjobb (az is lehet, hogy a legjobb) képességü tagja volt, ami már csak azért is komoly teljesítmény, mert az a mezőny kivételesen erős volt. Stikét mindenki ismerte, központi figura volt, köztudott volt róla, hogy éltanuló, a Népköztársasági Ösztöndíj elosztásakor kihagyhatatlan volt. Emellett aktív (egyes vélemények szerint hiperaktív) közösségi ember, a KISZ-ben is vállalt különböző szintű feladatokat, azt hiszem, először éppen az egyetemi KISZ-bizottságon találkoztunk. Én kémia-fizika tanárszakos hallgatóként Irinyi kollégista voltam, ő meg Eötvösös, ugyanaz az épület, így ott is elég gyakran öszszefutottunk, később pedig a Herman Ottó Kollégium felső két szintjén, ahol a fiatal házasok kaptak szobát. Sok párhuzamosság volt az életünkben. Mindketten első generációs értelmiségiek voltunk, nagyjából egyívású gyerekeink ugyanabba az óvodába jártak és a Herman után mindketten a Makkosházi lakótelepre költöztünk, panellakásba a családjainkkal. Egyetemi doktoranduszként egymás tágabb ismeretségi-baráti körébe tartoztunk, amibe belefért, hogy elmenjünk sörözni vagy a folyosón váltsuk a világot, sőt néha „családilag” még meg is látogattuk egymást. Mivel Stike a szerves kémia és a katalízis szerelmese volt, én meg inkább a szervetlen kémiát kedveltem, és az ennek megfelelő tanszékekre kerültünk, szakmai kapcsolat ebben az időben még nem volt közöttünk (meg aztán az ilyesmi a nyolcvanas évek ,szűk levegőjében” nem is tartozott a felülről támogatott kezdeményezések közé.)

Aztán jött a rendszerváltás. A legnagyobb átrendeződéseket hozó 90-es éveket Stike főként idehaza töltötte, az események sürüjében (persze azért néha el-elutazott egy időre külföldre), így az összes változásnál legalábbis jelen volt, de ahogy én ismertem, követte és ha lehetett, alakította is azokat. Ezzel szemben én 1993 és 2000 között Ausztráliában

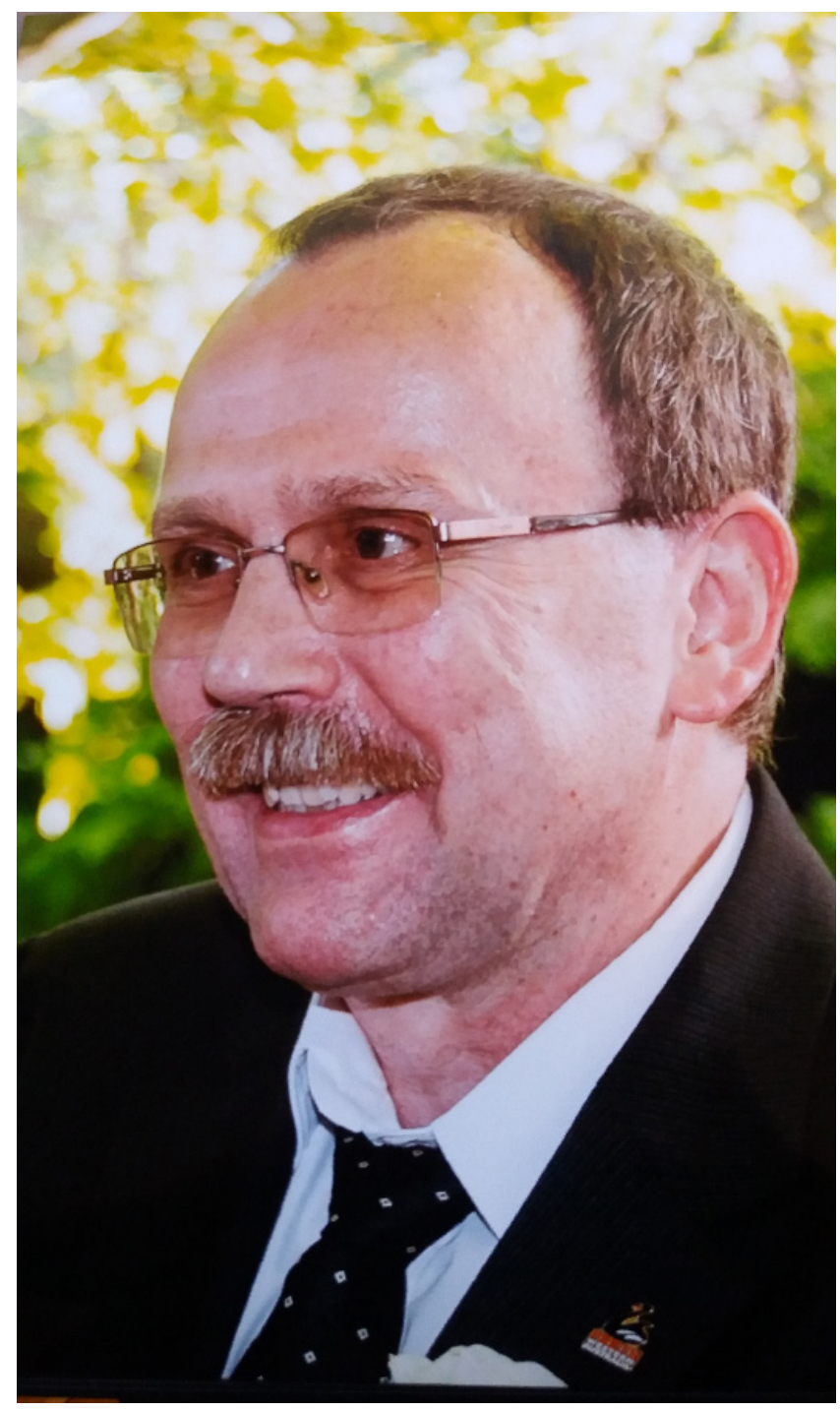

éltem és dolgoztam, így lemaradtam egy csomó dologról, de ha így jobban tetszik, lelazsáltam azokat. Amikor 2000-ben hazahozott a hon- és a kalandvágy, érthető módon nem ismertem rá arra az országra, amit 8 évvel azelőtt elhagytam. Értékes és a későbbiek szempontjából fontos felfedezés volt számomra, hogy Stike, mint világot látott ember, nem tekintett a „,külföldön megtollasodott és külföldröl hazaszakadt" szakmai ellenfélnek (mint oly sokan mások, sajnos). Ekkortájt volt egy nagyon fontos beszélgetésünk, aminek néhány részletére még ma is emlékszem. Stike arról pró-

* Tel.: +36 62544 054; e-mail: sipos@chem.u-szeged.hu 
bált meggyőzni, hogy publikálni kell, éspedig külföldön, angolul és sokat. Én meg amellett érveltem, hogy ipari alapkutatásokat kell behozni az egyetemre, ahol a megtermelt és áttételeken át az R\&D központokban hasznosítható háttértudás, ami az érték. Végül megállapodtunk abban, hogy nem értünk egyet, de még később többször visszatértünk erre a kérdésre. Élvezetes pengeváltások voltak és ma már tudjuk, hogy mindkettőnknek igaza volt.

A fordulópont aztán 2008-ban következett be. Mindketten akkor voltunk tudományos pályafutásunk mélypontján (egy újabb érdekes párhuzam). Se pályázatunk, se pénzünk, se sikeres kutatásunk és ebből írható publikációnk nem volt éppen egyikünknek sem, és még egy halom további gond, amit inkább nem is idéznék fel. Ekkor teljesen váratlanul, kaptam külföldről egy ipari megkeresést, a timföldgyártásnál használt tömény lúgos oldatok és a belőlük kiváló szilárd anyagok, pl. réteges kettős hidroxidok (LDH-k) kémiájának alapjai volt a tárgya. Az oldatkémia rész számomra ismerős terep volt, de LDH-król alig hallottam elötte, arra viszont emlékeztem, hogy Stike a nagydoktori védésén az LDHkról is beszélt, nem is keveset. Bekopogtam hozzá azzal, hogy hozzáértő társat keresek ehhez a projekthez, csináljuk meg együtt, fifti-fifti. Stike azonnal igent mondott, az alig néhány millió forintos projekt elindult, és ezzel megalakult a Kémia Intézet első tanszékeken átívelő kutatócsoportja. Néhány hónapon belül 4 hallgató csatlakozott hozzánk, később mind a négy nálunk $\mathrm{PhD}$-zett. Aztán a csoport nőni kezdett, újabb projektek jöttek, alapkutatások és ipari munkák, újabb feladatok, újabb tehetséges hallgatók. Beindultunk. Még nevünk is lett: Anyag- és Oldatszerkezeti Kutatócsoport, angolul Material and Solution Structure Research Group, MASOST. A témakörök is kiszélesedtek: csináltunk katalízist, szintetizáltunk nanoszerkezeteket, műveltünk oldatkémiát és szervetlen szintézist.

Azóta megszakítás nélkül együtt dolgoztunk Stikével, 14 PhD hallgató került ki a kezünk alól és további 10 cselekménye folyamatban van. A Web of Science alapján 113 közös referált közleményünk jelent meg az elmúlt 10 évben, a legsikeresebb évünk a tavalyi volt, 14 cikkel és két tized híján 70-es össz-impakttal.

Stikével dolgozni élmény volt. Hatalmas és folyamatosan karbantartott szakmai tudással rendelkezett. Munkabíró képessége hihetetlen (és számomra követhetetlen) volt, napi 12-14 órákat dolgozott, gyakran hétvégén is, a munka, a kémia volt az élete. (,Azt hiszem, jól áll nekem a kémia...”, szokta mondani.)

Amellett, hogy nagyon jól megértettük egymást, az utóbbi időkben már félszavakból is, fontos még, hogy egyszer sem vesztünk össze, pedig 2008-ban többen is azt mondták, hogy ez a két ember egy évet sem fog együtt dolgozni. Nem lett igazuk, a több mint egy tucat közösen eltöltött év alatt nagyon összecsiszolódtunk, megtanultunk hatékonyan egymás keze alá dolgozni. Egy idő után aztán annyira együtt kezelt bennünket a környezetünk, hogy előfordult: őt szólí- tották Palinak, vagy engem Pistinek. Bizonyos területeken komplementerek voltunk, másokon egymás antitézisei. Ö több kéziratot produkált, én inkább a pénzek beszerzésében voltam jó. Ő gyors volt, én lassú. Ö szigorú és szókimondó ember lévén szívesen vállalta a „rossz zsaru” szerepét a hallgatóknál, cserébe én lehettem a ,jó zsaru”, aki a lelküket ápolja. Ö bevállalós volt, szeretett „,bokszolni”, ugyanakkor ütésálló is volt $(, \ldots$ megerősödök tőle, ha nem csinálják velem, hiányzik...”). Én szívesebben elhajoltam a balegyenesek és a jobbhorgok elől. Határozott volt a döntéshozásban (nem úgy, mint én), de ha nem tudtunk véleményt egyeztetni, ügyelt arra, hogy ne hozzon kellemetlen vagy vállalhatatlan helyzetbe. Kemény ember volt, de csak kívül: amikor Hank, a kutyája elpusztult, engem hívott fel és nem szégyellte a sírást. Ha rossz volt valamiről a véleménye vagy nem értett velem egyet, azt is azonnal a tudomásomra hozta, s azt hiszem, ez kölcsönös volt. Mindig az volt az érzésem, hogy tartozom neki valamivel, ami megsokszorozta az ambícióimat. És hát igen: mióta meghalt, jelentősen csökkent azoknak az embereknek a száma, akiben feltétel nélkül megbízom.

Aztán ott volt a csoport, a MASOST. Amikor megalakult, a legmerészebb álmunkban sem gondoltuk volna, hogy ide fejlődik. Stike, aki nem volt érzelgős ember, úgy fogalmazott a fiataloknak, hogy ,ti vagytok a mi tudományos családunk". Én is úgy érzem, hogy egy kiváló csapat jött létre az évek során és tudom, hogy Stike is úgy gondolta, hogy ez tudományos életmüvünk közös részének egyik, ha nem a legfontosabb tétele. Bár a most következőkhöz hasonló gondolatokat a Magyar Kémikusok Lapja oldalain nemrég már közzétettem, itt is szeretnék erről írni néhány szót, mert ide kívánkoznak. Valamiért úgy alakult (és ennek a titkát már sem én sem más nem fogja tudni megfejteni), hogy a MASOST-ba került fiatalemberek pillanatok alatt megtanulták elsősorban egymástól, hogy hogyan kell egy tudományos közösségben élni, alkotni és viselkedni. A MASOST-nak ez a belső dinamikája magától, spontán módon alakult ki. Stikének meg nekem ebben nem volt elöre eltervezett, aktív szerepünk; sokszor úgy tünt, hogy elegendő a háttérből figyelnünk az eseményeket és rendelkezésre állni, amikor szükség van ránk, akár szakmai, akár emberi dolgokban. Nagyon sok olyan fiatal megfordult a kezeink között, akik eleve sziporkázóan tehetségesek voltak, de akadtak olyanok is, nem is egy, akik nálunk „,nőtték ki” magukat. Azt is megtanultuk az évek során, hogy egy $\mathrm{PhD}$ értekezéssel kapcsolatosan a témavezető legértékesebb tulajdonsága a türelem. A volt MASOST-osok pedig mind a mai napig visszajárnak, évente két olyan alkalom is van, amikor az „aktívak” és a már végzettek összejönnek, férjestől-feleségestől-gyerekestől. Mint egy nagy család.

A családregények szokásos felépítése a genezis - kiteljesedés - fénykor - hanyatlás - felbomlás. Stike a csoport fénykorában távozott el és ez egybeesett saját személyes fénykorával is. A szakma az utóbbi évekre ismerte fel igazán a képességeit és 2021-re a Kémiai Intézet intézetvezetője, a Magyar Kémikusok Egyesületének főtitkára, 
a MOL-GINOP mega-projekt projektvezetője, a Kémia Doktori Iskola helyettes vezetője, a Szerves Kémiai Tanszék tanszékvezetőhelyettese, MTA Doktori képviselö, az MTA Doktori Tanács tagja, továbbá az MTA Katalízis Munkabizottságának elnöke, hogy csak a legfontosabbakat említsem. Emellett vezette a kutatócsoportot, PhD témavezetője- és társtémavezetője volt 8 diáknak, elképesztő mennyiségű oktatási feladatot látott el, középiskolásokat mentorált, konferenciákra járt és konferenciákat szervezett, és még arra is maradt ideje, hogy az évfolyamtalálkozók szervezését is a vállára vegye - és ha eljutna eddig a pontig az olvasásban, Stike nem tudná kihagyni, hogy megjegyezze: tovább is van, mondjam még?

Imádta a mozdonyokat és a kutyákat, imádott utazni de ragaszkodott ahhoz, hogy maga takarítsa az irodáját. Új Mercedesének, álmai autójának érkezése előtt hónapokig tanulmányozta a szupermodern járgány gépkönyvét, hogy szakértővé képezze ki magát. Nagyon szerette a történelmi tárgyú könyveket, kedvenc filmjei a „Macskafogó” és a „Hófehér” voltak, de fejből idézett a „Gyalog galopp”-ból is. Politikai tájékozottsága is mindig zavarba ejtően naprakész volt és nem tudom, hogy talált rá időt, de mindig minden fontos dolog finomszerkezetének utána tudott járni. Válogatós volt az evésben, hús- (sült kacsacomb!) evő volt, a növényeket nem kedvelte (,...60 évente szoktam répát enni és már ettem egyszer...”). Viszont a „nagy” borokat nagyon szerette, évente egyszer a Bortér idején szervezett a csoportnak egy borkóstolást, amikor végig kóstoltunk egy általa kiválasztott borsort, ehhez ő celebrálta az egészen finom részletekbe is belemenő bemutatásukat. Társasága mindig felvillanyozó volt, sajátos, szabadszájú és gyakran vitriolos humorának megszámlálhatatlan termését ma is naponta idézzük. Nyelvi sziporkái közül (,,..zongoraleckét adok és veszek...”; „...mennyit fut százon két vödör víz- zel?”; „...nemzetközi birkát (= interjút) kell adnom...” „,... felgyorsult a lelassulás...”) sok még életében szállóigévé vált. Rajongott az unokáiért, mindig meglágyultak az arcvonásai, ha róluk beszélt.

Egy éve körül történt, hogy a körzeti orvosom rám szólt, pihenjek egy kicsit, mert a szívem rendetlenkedik. Felhívtam Stikét: „Houston, we got a problem!” Éreztem a reakcióján, hogy (amellett, hogy rá egyébként nem jellemző módon megijedt a hírtől) az futott át az agyán (meg persze az enyémen is), hogy mi lesz, ha itt hagyom egyedül ezzel a nagy csoporttal meg rengeteg feladattal. Azt nyilván mindketten tudtuk, hogy az megtörténhet (,,...azt olvastam valahol, hogy az emberek a végén meg szoktak halni..."), de azt hiszem, ismeretségünk során ekkor szembesültünk először azzal, hogy annak bizony következményei lesznek. Persze, aztán elhessegettük, talán el is felejtettük. Aztán jött az utolsó párhuzam: egyszerre kaptuk el ezt a buta kórságot, és bekövetkezett, csak fordítva. Itt van a sok félbehagyott feladat, befejezetlen munka, félig kész PhD projekt, megíratlan publikáció, egy el sem kezdett monográfia. Stike hatalmas ürt hagyott maga után és a szükebb, de a tágabb környezetében is jó ideig olyan érzése volt mindenkinek, mintha egy kataklizma után a romok felett állnánk. Persze, a kezdeti bénultság és apátia után hamar fel kellett ismerni, hogy menni kell tovább, csinálni kell a dolgunkat, tudni kell folytatni, és mint ahogyan azt Dr. Varsányiné tette, el kell kezdeni az egérirtást, akár hozott szalonnával. Lezárult egy korszak, nem csak a csoport, de bizonnyal az egész szegedi kémia történetében. Stike, mint viszonyítási pont úgyis mindig ott lesz. Sokáig és sokszor meg fogjuk még magunkat kérdezni, hogy ehhez vagy ahhoz vajon mit szólna, mi lenne róla a véleménye. Próbáljuk megszokni, hogy a választ nem tőle kapjuk meg. 


\section{Remembering professor István Pálinkó (1959-2021)}

The present contribution is an obituary to István Pálinkó, professor of chemistry who passed away at the age of 62 on the $26^{\text {th }}$ of March, 2021.

István Pálinkó was born in Kiskőrös in 1959, and accomplished his primary and secondary school studies in Kecskemét. He commenced his University courses in 1978 in the József Attila University of Science (currently University of Szeged) in chemistry major. He graduated in 1983 with high distinction (he was awarded with the so-called red diplome which is given only to those who have spotless academic record.)

Skipping the $d r$ of Univ degree, he received his Candidacy of chemical science degree (broadly equivalent to the currently used $\mathrm{PhD}$ ) in 1993, and defended his Doctor of Hungarian Academy of Science degree in 2007. István was employed by the Institute of Chemistry, Department of Organic Chemistry right after graduation and has worked there until he passed away. He become full professor in the same Department in 2014. At the time of his death, he held several high profile functions: he was the head of the Chemistry Department, the vice head of the Doctoral School of Chemistry, the vice head of the Department of Organic Chemistry, the general secretary of the Hungarian Chemical Society, the leader of the recently commenced collaborative GINOP project with the MOL Hungary, member of the Doctoral Council of the Hungarian Academy of Science, and president of the Hungarian Catalysis Workgroup, and these are only the most important ones. Add to these the teaching duties, the supervision of the $\mathrm{PhD}$ students, various mentoring activities (as he was a keen supporter of chemistry teaching in the secondary schools), participation and organization of scientific conferences. Not surprisingly, he was a real "workaholic", spent 12-14 hours in the Department, often over the weekends.

István had a very broad research interest. Indeed the organic catalysis was his main research field, however, he was very active and productive in several other areas too, such as inorganic syntheses, theoretical modelling, materials science, catalyst preparation (including all kinds of structural characterizations) - and the list is certainly not complete. István was famous for continuously creating brilliant new ideas and had an exceptional and permanently updated encyclopedic knowledge. As result of these, he had a plethora of collaborations throughout the World in almost all fields within chemistry.

He participated in various cooperation with Hungarian scientists from the Hungarian Academy of Sciences (MTA TTK), ELTE - Eötvös University, University of Szeged, and his international network included chemists from the UK, Sweden, Germany, and USA.

He was a very popular teacher of the Institute of Chemistry, University of Szeged: supervised more than a hundred BSc and MSc thesis works and $14 \mathrm{PhD}$ completed dissertations. $8 \mathrm{PhD}$ students were supervised by him at the time he passed away. His publishing activity was also excellent.

He was an internationally recognized scientist. He worked with world-famous chemists, like the Nobel-laurated George Oláh, Gábor Somorjai or Kenneth Seddon (and this is again an incomplete list.) He co-authored close to 300 refereed research papers with cumulative impact of ca. 570. Currently, he has more than 3200 independent citations to his works, but this number will certainly increase further in the near future. He was the holder both the Széchenyi and the Széchenyi Professorial Scholarships, and in 2004, the very prestigious George Olah award was presented to him.

In 2008, István was one of the two founders of the Materials and Solution Structure Research Group, or MASOST, as he called it "our scientific family". His sudden death was shocking to the research group as well as to the entire scientific community in Szeged, in Hungary and also to all those who knew him all around the World.

His passing away is a truly great loss to all of us. With this publication, we attempted to briefly summarize the memories that the author, the members of the MASOST and those who knew him, kept about István. 